\title{
SUMBER KEWENANGAN PEMERINTAHAN
}

\author{
Desri Tiara Salsabila \\ tiarasalsabila663@gmail.com \\ 1910003600246 \\ Univer sitas ekasakti
}

\author{
BAB I \\ PENDAHULUAN
}

\section{Latar Belakang}

Saya mengangkat judul ini dikarenakan Setiap Penyelenggara Negara, Pejabat Negara, dan Pejabat Pemerintahan memiliki legitimasi, yakni kewenangan yang diberikan oleh undang-undang, maka aparat pemerintah diakui dan dipatuhi oleh rakyatnya sehingga kewenangan atau wewenang yang diberikan oleh undangundang kepada aparat pemerintah harus memiliki legitimasi dari rakyat supaya rakyat tertib. "Kewenangan adalah apa yang disebut kekuasaan formal, kekuasaa yang berasal dari Kekuasaan Legislatif (diberi oleh Undang-Undang) atau dari Kekuasaan Eksekutif/Administratif. Kewenangan adalah kekuasaan terhadap segolongan orang-orang tertentu atau kekuasaan terhadap sesuatu bidang pemerintahan (atau bidang urusan) tertentu yang bulat, sedangkan wewenang hanya mengenai sesuatu onderdil tertentu saja. Di dalam kewenangan terdapat wewenang-wewenang. Wewenang adalah kekuasaan untuk melakukan sesuatu tindak hukum publik." Kewenangan dapat diperoleh dari 3 (tiga) cara, yakni diperoleh secara atribusi, delegasi, dan mandat. Kewenangan atribusi diperoleh melalui Undang-Undang, kewenangan non-atributif diperoleh dari mandat ataupun delegasi. Produk hukum dapat dibuat oleh Pejabat Publik yang memiliki kewenangan yang diperoleh dari kewenangan non-atributif untuk melaksanakan pemerintahan

\section{Rumusan Masalah}

Dalam kesempatan ini saya akan membahas rumusan masalah yang ada dalam sumber kewewenanga pemerintahan di indonesia.

1.Pengertian wewenang yang dapat diperoleh dalam tiga cara:
a) Dapat diperoleh secara atribun
b) Dapat diperoleh secara delegasi
c) Dapat diperoleh secara mandat 


\section{BAB II PEMBAHASAN}

\section{a) Pengertian Wewenang}

Dalam Hukum Administrasi Negara tentu kita tidak asing mendengar istilah wewenang, karena sebenarnya wewenang sekaligus menjadi batasan kekuasaan untuk berbuat sesuatu dan tidak berbuat sesuatu. Secara umum Wewenang dalam Hukum Administrasi Negara adalah Kekuasaan menggunakan sumberdaya untuk mencapai tujuan organisasi dan secara umum tugas di definisikan sebagai kewajiban atau suatu pekerjaan yg harus dikerjakan seseorang dalam pekerjaannya. Menurut kamus besar bahasa indonesia, kata wewenang disamakan dengan kata kewenangan, yang diartikan sebagai hak dan kekuasaan untuk bertindak, kekuasaan membuat keputusan, memerintah dan melimpahkan tanggung jawab kepada orang/badan lain. ) Menurut Frans Magnis Suseno kewenangan adalah kekuasaan yang dilembagakan. ) Menurut H.D Stoud kewewenangan adalah keseluruhan aturan-aturan yang berasal dari hukum organisasi pemerintahan, yang dapat dijelaskan sebagai seluruh aturan-aturan yang berkenaan dengan perolehan dan penggunaan wewenang-wewenang pemerintahan oleh subjek hukum publik didalam hubungan hukum publik. Sedangkan dalam Black Law Dictionary kewenangan diartikan lebih luas, tidak hanya melakukan praktek kekuasaan, tetapi kewenangan juga diartikan dalam konteks menerapkan dan menegakan hukum, adanya ketaatan yang pasti, mengandung perintah, memutuskan, adanya pengawasan yuridiksi bahkan kewenangan dikaitkan dengan kewibawaan, kharisma bahkan kekuatan fisik. Wewenang merupakan konsep inti dalam hukum tata negara dan hukum administrasi negara. sebab didalam wewenang tersebut mengandung hak dan kewajiban, bahkan di dalam hukum tata negara wewenang dideskripsikan sebagai kekuasaan hukum (rechtskracht). ) Artinya hanya tindakan yang sah (berdasarkan wewenang) yang mendapat kekuasaan hukum (rechtskracht). ) Sementara itu menurut Bagir Manan sebagaimana dikutip oleh Ridwan HR mengatakan bahwa wewenang dalam bahasa hukum tidak sama dengan kekuasaan. Kekuasaan hanya menggambarkan hak untuk berbuat dan tidak berbuat. Wewenang sekaligus berarti hak dan kewajiban.

1 Sedangkan menurut G.R.Terry Wewenang dalam Hukum Administrasi Negara adalah kekuasaan resmi dan kekuasaan pejabat untuk menyuruh pihak lain supaya bertindak dan taat kepada pihak yang memiliki wewenang itu, Menurut R.C.Davis dalam bukunya, Fundamentals of Management: Authority/Wewenang dalam Hukum Administrasi Negara adalah hak yang cukup, yang memungkinkan seseorang dapat menyelesaikan suatu tugas/kewajiban tertentu. Jadi, wewenang adalah dasar untuk bertindak, berbuat dan melakukan kegiatan/aktivitas perusahaan. Tanpa wewenang orang-orang tidak dapat berbuat apa-apa, Sejauh ini tugas hanya diartikan menjadi sesuatu yg sudah sewajibnya dan harus dilakukan bagi seorang individu dalam suatu pekerjaannya, mungkin saja dalam aktifitas nya juga. Kesimpulan akhir bahwa tugas dan wewenang memang memiliki perbedaan 
tetapi tetap dalam suatu hubungan seperti yg dikatakan oleh R.C Davis bahwa tanpa wewenang orang-orang di dalam perusahaan tidak dapat berbuat apa-apa. Dengan kata lain penyertaan tugas juga berhubungan dengan wewenang., Tugas pemerintah Indonesia itu cukup luas, salah satunya adalah pemerintah wajib berusaha memberikan perlindungan kepada masyarakat baik dibidang politik maupun dalam sosial ekonominya dan untuk itu pemerintah mendapat freies Ermessen atau kewenangan untuk turut campur dalam berbagai kegiatan sosial, seperti melakukan pengaturan dalam kegiatan-kegiatan dimasyarakat dengan memberi izin, lisensi, dispensasi dan lain-lain atau melakukan pencabutan atas hak-hak Kewenangan dalam bahasa hukum tidaklah sama dengan kekuasaan hal tersebut dikarenakan bahwa kekuasaan hanya menggambarkan suatu hak untuk berbuat ataupun tidak berbuat, dan kalau wewenang dalam hukum sekaligus berarti hak dan kewajiban (rechten enplichten). Dan dalam otonomi daerah hak mengandung arti kekuasaan untuk mengatur sendiri dan mengelola sendiri

\section{A. Asas Legalitas HAN} administrasi

Azas legalitas dalam HAN, bahwa semua perbuatan dan keputusan pejabat harus didasarkan pada kewenangan yang diberikan oleh peraturan perundangundangan. Jika tidak adanya norma dan atau norma tersamar, azas kewenangan tersebut harus menggunakan azas-azas umum pemerintahan yang baik (Principle of Proper Administration). Dalam menentukan suatu tindakan maka harus mencakup 2 hal utama, yakni pertama adanya kewenangan sebagai sumber munculnya suatu tindakan, dan yang

kedua adalah adanya norma atau subtansi norma, apakah norma yang sudah jelas ataupun

masih merupakan norma tersamar. Norma tersamar ini yang kemudian memunculkan

penggunaan azas-azas umum pemerintahan yang baik (Principle of Proper Administration).

\section{B. Prinsip Dasar Kewenangan}

Pejabat administrasi bertindak dan mengambil keputusan atas dasar kewenangan yang dimilikinya. Kedua, kewenangan yang dipergunakan harus dapat dipertanggungjawabkan dan diuji baik oleh norma hukum atau pun azas hukum. Kewenangan (authority) adalah kekuasaan formal yang dimiliki oleh Badan dan atau pejabat administrasi atau penyelenggara negara lainnya untuk bertindak dalam laporan hukum publik yang meliputi beberapa wewenang. Kewenangan menurut Prof. Prajudi Atmosudirjo merupakan kekuasaan terhadap segolongan orang-orang tertentu atau kekuasaan terhadap suatu bidang pemerintahan tertentu yang bulat. Menurut Prof. Eko Prasojo, kewenangan selalu melakat terhadap orang, terhadap urusan, dan pemberi kewenangan. Wewenang sendiri merupakan hak yang dimiliki oleh Badan atau pejabat atau penyelenggara negara lainnya untuk mengambil keputusan dan atau tindakan dalam penyelenggaraan 
pemerintahan. Di dalam kewenangan terdapat beberapa wewenang yang di dalam wewenang itu sendiri ada hak-hak tertentu yang terkandung.

\section{Sumber Kewenangan}

Kewenangan pejabat administrasi berasal dari undang-undang yang dibuat oleh legislatif melalui suatu legitimasi yang demokratis. Hukum menyebabkan bahwa apabila penguasa ingin memberikan kewajiban-kewajiban kepada masyarakat, maka kewenangan itu harus diatur dalam undang-undang.Sengketa Kewenangan: klaim penggunaan kewenangan wewenang yang dilakukan olehdua pejabat pemerintahan atau lebih yang disebabkan oleh tumpang tindih atau tidakjelasnya pejabat pemerintahan yang berwenang menangani suatu urusan pemerintahan.Sengketa itu sendiri mencakup 3 hal, yakni Lokus (tempat), Tempus (waktu), dan materi.Cara Diperolehnya Kewenangan : Pertama, melalui atribusi, yaitu pemberiankewenangan yang baru berasal dari konstitusi dan atau undangundang. Kedua, melalui delegasi, yaitu pemindahan atau pengalihan suatu kewenangan yang ada. Ketiga, melaluipemberian mandat, yaitu kewenangan yang diberikan oleh suatu organisasi pemerintahankepada orang lain untuk mengambil keputusan atas nama pemberi mandat.

\section{Sumber-Sumber Kewenangan}

Kewenangan yang diberikan karena adanya pelimpahan/peralihan wewenang. Setiappenyelenggaraan kenegaraan dan pemerintahan harus memiliki legitimasi, yaitukewenangan yang diberikan oleh undang-undang. Dalam hukum Administrasi, dikenal 3(tiga) sumber kewenangan, yaitu atribusi, delegasi, dan mandat.

\section{1) Atribusi}

Atribusi adalah pemberian wewenang pemerintahan oleh pembuat undang-undang kepada organ pemerintahan. Berdasarkan Undang-Undang No. 30 Tahun 2014 tentang Administrasi Pemerintahan (UU Administrasi Pemerintahan), Atribusi adalah pemberian Kewenangan kepada Badan dan/atau Pejabat Pemerintahan oleh Undang-Undang Dasar

Negara Republik Indonesia Tahun 1945 atau Undang-Undang. Atribusi juga bisa dikatakan sebagai bentuk kewenangan yang didasarkan atau diberikan oleh UUD atau Undang-Undang kepada suatu lembaga negara/pemerintahan. Kewenangan tersebut terus menerus dan dapat dilaksanakan atas prakarsa sendiri setiap waktu diperlukan, sesuai dengan batas-batas yang diberikan. Badan dan/atau Pejabat Pemerintahan memperoleh Wewenang melalui Atribusi apabila:

a) Diatur dalam Undang-Undang Dasar Negara Republik Indonesia Tahun 1945 dan/atau undang- undang;

b) Merupakan Wewenang baru atau sebelumnya tidak ada; dan

c) Atribusi diberikan kepada Badan dan/atau Pejabat Pemerintahan.

Tanggung jawab Kewenangan berada pada Badan dan/atau Pejabat Pemerintahan yang bersangkutan. Adapun contoh dari adanya delegasi adalah sebagai berikut: OJK Resmi Ambil Alih Tugas BI Awasi Perbankan Setelah melalui proses panjang, akhirnya pengalihan pengawasan perbankan dan non perbankan resmi 
dilimpahkan kepada Otoritas Jasa Keuangan (OJK) mulai 1 Januari 2014.

Sebelumnya, tugas tersebut selama ini berada di tangan Bank Indonesia (BI). Berlangsung di kantor Bank Indonesia (BI), transisi pengawasan ini ditandai dengan serah terima fungsi pengaturan dan pengawasan mikro prudensial oleh Gubernur Bank Indonesia (BI) Agus Martowardojo kepada Ketua OJK Muliaman D Hadad. Dalam acara pengalihan fungsi ini, turut hadir seluruh jajaran BI dan OJK. Kedua lembaga ini berbaur menjadi satu demi tujuan bersama untuk meningkatkan pengawasan sistem perbankan, non perbankan dan pasar modal di Tanah Air. Menurut Agus Martowardojo, pengalihan fungsi ini merupakan pondasi untuk menghadapi tantangan global untuk membangun sistem keuangan dan pengawasan diindustri perbankan, non bank dan pasar modal. "Pengalihan fungsi pengaturan dan pengawasan bank dari BI ke OJK menjadi tonggak bersejarah untuk menghadapi sistem keuangan yang kuat. Sehingga kita akan semakin kuat dalam menghadapi shock global," terang dia saat memberi sambutan di acara Transisi Pengawasan Bank di kantornya, Jakarta, Selasa (31/12/2013). Penyerahan tugas tersebut merupakan langkah pelaksanaan amanah Undang-undang (UU) Nomor 21 Tahun 2012 tentang OJK. Selama ini, tambah Agus, kekuatan sistem keuangan Indonesia mampu menyerap shock global dengan baik. Hal ini dibuktikan dengan stabilnya kinerja sektor perbankan. "Kemampuan modal, likuiditas dan profitabilitas sektor perbankan di Indonesia sangat kuat dan stabil. Semua ini dihasilkan dari perilaku manajemen perbankan yang menerapkan budaya risiko yang baik dan menjalankan aspek kepatuhan," tandasnya. Dia optimistis, masa transisi dapat berjalan dengan baik. Tidak ada perubahan pengaturan, perizinan dan lainnya. Ini adalah permulaan bagi OJK untuk menjaga stabilitas sistem keuangan yang berkontribusi terhadap perekonomian Indonesia. Dalam hal ini, OJK tidak akan berjalan sendiri karena didukung oleh pemerintah, Lembaga Penjamin Simpanan (LPS) dan lembaga lain serta putra putri terbaik dari BI.

"Kami mendukung penuh putra putri BI untuk mengawal masa transisi ini supaya dapat tercipta sistem keuangan yang terintegrasi dengan OJK. Integritas dan kompetensi akan tetap melekat di mana putra putri ini bertugas serta terus menjunjung tinggi etos kerja," pungkas Agus.

\section{2) Delegasi}

Delegasi adalah pelimpahan wewenang pemerintahan dari satu organ pemerintahan kepada organ pemerintahan lainnya. Berdasarkan UU Administrasi Pemerintahan, delegas adalah pelimpahan Kewenangan dari Badan dan/atau Pejabat Pemerintahan yang lebih tinggi kepada Badan dan/atau Pejabat Pemerintahan yang lebih rendah dengan tanggung jawab dan tanggung gugat beralih sepenuhnya kepada penerima delegasi.

\section{a. Badan dan/atau Pejabat}

Pemerintahan memperoleh Wewenang melalui Delegasi apabila:

a) Diberikan oleh Badan/Pejabat Pemerintahan kepada Badan dan/atau Pejabat Pemerintahan lainnya;

b) Ditetapkan dalam Peraturan Pemerintah, Peraturan Presiden, dan/atau Peraturan 
Daerah; dan

c) Merupakan Wewenang pelimpahan atau sebelumnya telah ada.

Tanggung jawab Kewenangan berada pada penerima Delegasi. Adapun contoh dari adanya manndat adalah sebagai berikut:

Surat Perintah Sebelas Maret

Surat Perintah Sebelas Maret atau Surat Perintah 11 Maret yang disingkat menjadi Supersemar adalah surat perintah yang ditandatangani oleh Presiden Republik Indonesia Soekarno pada tanggal 11 Maret 1966.

Surat ini berisi perintah yang menginstruksikan Soeharto, selaku Panglima Komando Operasi Keamanan dan Ketertiban (Pangkopkamtib) untuk mengambil segala tindakan yang dianggap perlu untuk mengatasi situasi keamanan yang buruk pada saat itu.

Surat Perintah Sebelas Maret ini adalah versi yang dikeluarkan dari Markas Besar Angkatan Darat (AD) yang juga tercatat dalam buku-buku sejarah. Sebagian kalangan sejarawan Indonesia mengatakan bahwa terdapat berbagai versi Supersemar sehingga masih ditelusuri naskah supersemar yang dikeluarkan oleh Presiden Soekarno di Istana Bogor.

\section{3) Mandat}

Mandat terjadi jika organ pemerintahan mengizinkan kewenangannya dijalankan oleh organ lain atas namanya. Berdasarkan UU Administrasi Pemerintahan, mandat adalah pelimpahan kewenangan dari Badan dan/atau Pejabat Pemerintahan yang lebih tinggi kepadaBadan dan/atau Pejabat Pemerintahan yang lebih rendah dengan tanggung jawab dan tanggung gugat tetap berada pada pemberi mandat. Badan dan/atau Pejabat Pemerintahan memperoleh Mandat apabila:

1. Ditugaskan oleh Badan dan/atau Pejabat Pemerintahan di atasnya; dan

2. Merupakan pelaksanaan tugas rutin.

a.Tanggung jawab Kewenangan tetap pada pemberi Mandat. Adapun contoh dari adanya mandat adalah sebagai berikut:

Cegah Tim Gadungan, SBY Minta Jokowi Berikan Mandat pada Tim

9 Ibid., hal 1

10 Ibid., hal 1

11 Ibid., hal 2

Untuk mencegah adanya tim gadungan yang meminta berkomunikasi dan berkonsultasi dengan pemerintah, Presiden Susilo Bambang Yudhoyono meminta presiden terpilih, Joko Widodo memberikan mandat kepada tim transisi atau orang-orang yang ditunjuk melakukan koordinasi. "Supaya tertib, dari pihak Pak Jokowi akan memberikan mandat kepada siapa yang akan berkomunikasi dengan kita secara tertulis, disebutkan si a, si b, si c, si d, dan ditandatangani oleh beliau," katanya, Jumat (5/9). Ia mengatakan ketika bertemu dengan Jokowi di Bali, sudah ada permintaan untuk koordinasi dengan para menteri. Ia melihat materi yang diajukan lebih banyak materi bidang perekonomian, polhukam, serta hal-hal yang bersifat umum. Karena itu, tiga menko dan Mensesneg akan menjadi pintu masuk bagi tim transisi Jokowi untuk melakukan komunikasi. "Berarti saya mandatkan 
kepada tiga Menteri Koordinator, untuk siapa bertemu dengan siapa. Sedangkan yang umum, soal-soal kelembagaan, house keeping lembaga Kepresidenan, urusan Pengamanan Presiden misalnya Danpaspamres dengan tim, sudah diterima oleh Presiden terpilih menjelaskan a, b, c, d, dan yang lain-lain. Kalau itu biar Menteri Sekretaris Negara yang mengkoordinasikan. Sedangkan saya dan Wapres memberikan supervisi agar semuanya berlangsung dengan baik," katanya.

12 Konsekuensi yuridis wewenang yang dimiliki seorang pejabat akan berbeda apabila wewenang tersebut bersumber dari pelimpahan wewenang (delegasi) maupun penugasan (mandat). 


\section{KESIMPULAN}

Wewenang dalam hukum administrasi negara merupakan kekuasaan menggunakan sumber daya untuk mencapai tujuan organisasi dan juga kemampuan untuk bertindak sesuai

dengan kekuasaan yang sah. Dan secara azaz legalitas dalam han bahwasanya semua perbuatan pejabat administrasi harus didasarkan pada kewenangan yang diberikan oleh peraturan perundang-undangan.dan sumber-sumber wewenang itu ada 3 yaitu yang pertama atribusi, pemberian kewenangan pada badan atau lembaga/pejabat negara tertentu baik oleh pembentuk Undang-Undang Dasar maupun pembentuk Undang-Undang. Yang kedua delegasi, adalah penyerahan atau pelimpahan kewenangan dari badan/lembaga pejabat tata usaha Negara lain dengan konsukuensi tanggung jawab beralih pada penerima. Dan yang

ketiga mandat, adalah pelimpahan kewenangan dan tanggung jawab masih dipegang oleh Pemberi Mandat. Konsekuensi yuridis wewenang yang dimiliki seorang pejabat akan berbeda apabila wewenang tersebut bersumber dari pelimpahan wewenang (delegasi)

maupun penugasan (mandat).

\section{DAFTAR PUSTAKA}

Radar, hukum. "Wewenang dalam Hukum Administrasi". 2017. https://www.radarhukum.com/wewenang-dalam-hukum-administrasi-negara.html 
diakses pada tanggal 27 oktober 2019 pukul 10.00 wib Marbun, Moh. Mahfud MD, SF. 2009. Wewenang dalam hukum administrasi negara.

Jakarta : Airlangga.

Ridwan, H.R. 2002. Hukum Administrasi Negara. Jakarta : Raja Grafindo

Persada.

Arbaben, Agus Roni.'Pengertian Kewenangan, Sumber-sumber Kewenangan, dan Kewenangan Membentuk Undang-undang". 2017.

https://agusroniarbaben.wordpress.com/2017/06/03/pengertian-kewenangansumber-sumber-kewenangan-dan-kewenangan-membentuk-undang-undang/ diakses tanggal 28 oktober 2019 pukul 12.00 wib

Zkakngmas."Sumber Kewenangan Hukum Administrasi Negara". 2013. https://zkakangmas.wordpress.com/2013/08/31/sumber-kewenangan-hukumadministrasi-negara/ diakses pada tanggal 25 oktober 2019 pukul $09.00 \mathrm{wib}$ Associates, \& RIS. "Kenali Kewenangan Atribusi Delegasi dan Mandat".2018. https://ris.legal/yuk-kenali-kewenangan-atribusi-delegasi-dan-mandat/ diakses pada tanggal 27 oktober 2019 pukul 11.00 wib

Cingkariak. "Contoh Delegasi Atribusi dan Mandat". 2015.

http://anakhukumbaru.blogspot.com/2015/01/contoh-delegasi-atribusi-danmandat.html diakses pada tanggal 28 oktober 2019 pukul 13.00 wib.

Arsyad, Arwan."Atribusi Kewenangan Delegasi dan Mandat".

2011.http://arwanarsyad.blogspot.com/2011/06/atribusi-kewenangan-delegasidan-

mandat.html diakses pada tanggal 28 oktober 2019 pukul 15.00 wib 